\title{
Symmetric and Asymmetric influence of Exchange Rate Fluctuations on the Money Demand in Malaysia: New Evidence from Non Linear ARDL Approach
}

\author{
Hussin Abdullah and Shehu El-Rasheed
}

\begin{abstract}
Preceding investigations on the effects of exchange rate on money demand has assumed a linear relationship between exchange rate and money demand thereby estimating a linear models. This study adopted the Shin et al. (2014) Nonlinear ARDL model to investigate the asymmetric effects of exchange rate on money demand for Malaysia. Annual data for money supply, GDP, interest rate and exchange rate for the period 1975 to 2016 were employed. The results show that Malaysian Ringgit depreciation and appreciation exerts an asymmetric effects on the money demand over both short run and long run period. The implication is that the effect of exchange rate fluctuations on money demand is more through the expectations channels rather than the wealth effect.
\end{abstract}

Keywords - Asymmetric effect, money demand, Nonlinear ARDL, Malaysia

\section{Introduction}

It has been emphasized that money demand plays a vital role in monetary policy design as well as in macroeconomic modelling (Bae \& De Jong, 2007). This is so especially for an emerging open economy like Malaysia that pursues inflation targeting using the short term interest rates. Despite the popular view that the demand for money function plays a minimal role under a short term interest rate targeting or inflation targeting frameworks, it is still argued that money demand is vital in monetary policy decision more especially to a middle income country like Malaysia, where the monetary policy does not function solely through the interest rate channel alone (Hossain \& Arwatchanakarn, 2017). Thus, money demand will provide a significant information regarding the country`s portfolio allocations.

A well specified money demand function is still significant even under an inflation targeting regime. Malaysian economy just like other Asian countries is characterized by a vulnerable macroeconomic fundamentals, including the rigidity in the foreign exchange dealings, foreign capital inflows, a financial system dominated by banks identified with a weakness in risk

Hussin Abdullah

School of Economics, Finance and Bank, Universiti Utara Malaysia Malaysia

Shehu El-Rasheed

Department of Economics and Development Studies, Federal University Kashere, Nigeria management. Macroeconomic vulnerabilities stem from a global fall in exports demand and financial markets rigidities (Quadry, Mohamad, \& Yusof, 2017).

Fluctuations in exchange rate is considered harmful to virtually all the macroeconomic indicators like the interest rate, inflation, imports, exports, investment and the likes. Different literatures have established linkages between each macroeconomic variable and the domestic currency exchange rate. This equally applies to the money supply-exchange rate nexus. Most published works on the money supply and exchange rate relationships are tailored towards the symmetry assumptions. In the money supply and exchange rate relationship, Mundel (1963) first introduced the exchange rate as one key determinant of money demand function alongside income and interest rate.

Focusing on unveiling the factors influencing the demand for money, Mundell (1963) identified exchange rate in addition to income and interest rate as the main determinants of money demand. A depreciation in the home currency signifies an appreciation in trading partner's currency, a situation that uplift the domestic currency value of foreign assets held locally. If such has been conceived as a rise in wealth holding by domestic residents, then money demand should rise (Arango\& Nadiri, 1981). Nonetheless, an appreciation of foreign currency followed by a further expectation of an appreciation, local residents may decide to keep more of foreign currency and lower their demand for local currency (Bahmani-Oskooee \& Pourheydarian, 1990). Hence, depending on the strength of either wealth or expectation effects, money demand could move in any of the directions.

Previous studies failed to provide the significant impact of exchange rate changes on the determination of money demand in Malaysia due to the assumption of a symmetric adjustment process. There is little to believe that appreciation and depreciation have a symmetric adjustment process. The 1997 Asian financial crisis saw the pegging of Malaysian Ringgit at RM3.80 to one United States (US) dollar, which was later floated in July, 2005(Quadry, Mohamad, \& Yusof, 2017). Thereafter, it continued to fluctuate against the US dollar reaching to RM4.2460 per US dollar in 2015 (Bank Negara, 2015). Depreciation of the Malaysian Ringgit has been an issue of serious concern more especially to the policy makers, investors, exporters, importers as well as other multinational corporations. This study will help in identifying how appreciation/depreciation in Malaysian Ringgit will affect money demand by economic agents and help in portfolio decisions.

This study employ the Nonlinear ARDL model developed by Shin et al. (2014) to check for the asymmetric effects of 
exchange rate using the partial sum decomposition. Our study`s main contribution to the current literature on exchange rate-money demand nexus is placed on its investigation into the possible asymmetric association amongst the variables in the money demand function. Considering asymmetric relationship is vital because a negative or positive changes on a particular variable might not bear similar influence on the other variable (Shin et al, 2014). The presence of an asymmetric association between two series can be as a results of several factors one of which pertains the complexity of the economic systems and of the mechanisms that generates the variable under study. Such complexity might create different avenues through which one variable influence another.

The rest of the paper is structured as follows. The following section 2 review the literature, Section 3 is data and methodology, while section 4 is results and discussion. Section 5 is summary and conclusion.

\section{Literature Review}

Nobel Laureate, Mundell (1963) first established that exchange rate of a domestic currency in terms of other trading partners' currencies do influence money demand. They provided the basis of how exchange rate will influence money demand in an open economy. It is viewed from the foreign sector that changes in exchange rate plays a significant role in the domestic money demand behavior (Arango \& Nadiri, 1981). Literature on currency substitution suggest that portfolio movements amongst the domestic and foreign currency provides a role for exchange rate. Two effects on the demand for local currency will result from changes in the foreign currency exchange rate. First, there is a wealth effect since depreciation in the domestic currency leads to a rise in the local price of foreign currency denominated securities with resultant effect on the portfolio adjustments. Assume that a wealth holders do evaluate their asset portfolios in terms of local currency, a fall in the value of the local currency exchange rate that rises the value of foreign assets held by local residents would boost their wealth (a wealth-enhancing effects). This in turn leads to a rebalancing effect because to enable them maintain a given share of their wealth invested in local assets, they have to repatriate a portion of their foreign assets holdings to domestic assets, including the domestic currency (i.e rebalancing). Arango and Nadiri (1981) further argued that it is because of the "rebalancing effect" brought about by changes in the exchange rate, that an exchange rate depreciation has a positive effect on the money demand. Therefore, depreciation in the exchange rate will rise the domestic currency demand.

Alternatively, changes in the exchange rate would generate a currency substitution effect at which the major role is played by investors' expectations. From the currency substitution view, as a weak local currency build up expectations for further depreciations, holders of assets will respond by moving part of their portfolios away from the local currency into a foreign assets.

Movements in exchange rate will influence the investor's portfolio mix amongst the domestic and foreign assets holdings. Specifically, an international investor realized a wealth increase (measured in domestic currency) when domestic currency depreciates. Portfolio balance approach postulates that an investor can retain a given share of his wealth invested in the domestic economy, and also substitute some of his foreign assets for domestic assets. This will rise the domestic monetary base leading to a fall in the domestic interest rates and a rise in money demand (Mcgibany \& Nourzad, 1995).

Empirical evidence has shown that money demand has been a central focus in modelling macroeconomic relationships and also a vital tool for monetary policy frameworks (Bae \& De Jong, 2007).A cursory look at the literature show that few studies focus on the effect of exchange rate on money demand. These among others includes; Arango and Nadiri (1981), McNown and Wallace (1992), Bahmani-Oskooee and Rhee (1994), Tan (1997), Ibrahim (2001), Arize and Nam(2012). Tan (1997) investigated the effect of exchange rate changes on the narrow (M1) and broad (M2) money for Malaysia. His findings show that exchange rate has a significant influence only on M1 and no effect on M2. In a similar study, Ibrahim (2001) study the role of financial factors (including exchange rate) in the behavior of M1 and M2 for Malaysia. His study concludes that exchange rate exerts a negative effect on money demand. Arize and $\operatorname{Nam}(2012)$ using a quarterly data for the period 1973-2009 investigated the effects of exchange rate variations on money demand functions for seven Asian countries. Using different error correction techniques, they established that exchange rate depreciation has a positive and significant influence on money demand at both short and long run in all the countries.

All the literatures reviewed above share a common characteristic that they are all built on the assumption that exchange rate fluctuations have a symmetric effects on the money demand. That is if depreciation is expansionary, appreciation is contractionary and vice versa. However, it is possible for exchange rate fluctuations to have asymmetric effects on money demand (Bahmani-Oskoee and Bahmani, 2015). As indicated in the literature reviewed, few studies were conducted on the relationship between exchange rate and money demand in Malaysia. Nevertheless, to the best of our knowledge, the methodology of asymmetry and non-linearity has not been considered in the previous studies. The greater attention of studies on money demand in Malaysia is on the identification of correct measure of money supply for policy use and the stability in the function. This study attempt to estimate the effects of exchange rate on the Malaysian money demand for the period the country adopted the market determined exchange rate system. Some studies have ignored changes in market expectations and institutional factors taking place under fixed and floating exchange rate system.

For these reasons, we decided to examine Malaysia`s exchange rate-money demand relationships. Annual data on broad money, exchange rate, income (GDP), interest rate and inflation (CPI) for the period 1975-2016 were collected from the World Development Indicators of the World Bank. All variables are transformed into their natural logarithmic form for consistent and reliable empirical results (Shahbaz et al. 2016). The sample period covered encompasses a different portfolio of monetary regimes that can make it possible to obtain additional information regarding the necessity to identify the workings of money demand. 


\section{Data and Methodology}

A standard money demand function comprises of a scale variable and opportunity cost variable(s). Usually aggregate output (income) is taken as scale variable while interest rate represents the opportunity cost variable. The model for money demand function is expressed thus;

$$
\ln M D_{t}=\varphi+\operatorname{aln} G D P_{t}+b I T R_{t}+c \ln E X R_{t}+\varepsilon_{t}
$$

Where $M D$ is aggregate money supply, GDP gross domestic product a proxy for income, ITR is interest rate, and $E X R$ is the exchange rate while $\varepsilon$ is the error term. The subscript $t$ represents time period. All variables are expressed in their natural logarithms. Expectedly, coefficients of income is positive, interest rate is negative, while exchange rate could be negative or positive depending on the either currency substitution or wealth effect (Arango \& Nadiri, 1981). In the Less Developed countries money demand literature, the argument of whether to consider inflation as the most appropriate opportunity cost variable or to take interest rate has been there for long. However, Arize and Nam (2012) argued that omitting interest rate in money demand model particularly for Asian countries will lead to a misspecification problem. The interest rate liberalization policies adopted by the Asian countries led to a great transformation in the money market and ease data availability (Arize \& Nam 2012). Nevertheless, few studies investigated the asymmetric effects of exchange rate changes on the money demand in emerging economies, and their conclusions have been mixed.

The model in Equation (1) can be re-specified in an error correction form based on the Pesaran et al. (2001) thus;

$$
\begin{gathered}
\Delta \ln M D_{t}=\delta+\sum_{i=1}^{n l} a_{i} \Delta \ln M D_{t=1}+\sum_{i=0}^{n 2} b_{i} \Delta \ln G D P_{t-1}+ \\
\sum_{i=0}^{n 3} c_{i} \Delta I T R_{t-1}+\sum_{i=0}^{n 4} d \ln E X R_{t-1}+\rho_{0} \ln M D_{t-1}+ \\
\rho_{1} \ln G D P_{t-1}+\rho_{2} \ln I T R_{t-1}+\rho_{3} \ln E X R_{t-1}
\end{gathered}
$$

Equation (2) is an unrestricted error correction specification based on the Pesaran et al. (2001) bound testing method of estimating short and long run coefficients. The equation also tests for cointegration using the F-test for joint significance of lagged level variables.

Previous studies estimated model of equation (2) using different methods on the assumption that exchange rate has a symmetric effects on money demand. However, Shin et al. (2014) established that an upward swing and a down ward swing are not adjusted at equal pace. This is because the appreciation and depreciation might have a different effect in terms of magnitude and size on the money demand. Hence the impact of exchange rate variations on money demand could be asymmetric. Therefore, this study following Shin et al (2014) decomposed the Malaysian Ringgit exchange rate into its negative (depreciation) and positive(appreciation) using partial sum method (Shin et al.2014).

Exchange rate is decomposed as follows;

$$
\ln E X R=\ln E X R_{0}+\ln E X R_{t}^{+}+\ln E X R_{t}^{-} ;
$$

where $\ln E X R_{t}^{+}$and $\ln E X R_{t}^{-}$are a partial sum output

of $\ln E X R$ drawn from the following equations;

$\ln E X R_{t}^{+}=\sum_{j=1}^{t} \Delta \ln E X R_{j}^{t}=\sum_{j=1}^{t} \max \left(\Delta \ln E X R_{j}, 0\right) ;$ $\ln E X R_{t}^{-}=\sum_{j=1}^{t} \Delta \ln E X R_{j}^{-}=\sum_{j=1}^{t} \max \left(\Delta \ln E X R_{j}, 0\right)$;
The asymmetric cointegration is based on the partial sum decomposition through Equations (3) and (4) which introduced a non-linearity into the model. Equations (3) and (4) depicts a positive changes (appreciation), and a negative changes (depreciation) of the local currency respectively. The exchange rate variable is replaced in Equation (2) by the two series obtained from the decomposition process that is $\ln E X R_{t}^{+}$and $\ln E X R_{t}^{-}$and thereby producing Equation (5).

$$
\begin{aligned}
& \Delta \ln M D_{t}=\delta+ \sum_{i=1}^{n 1} a_{i} \Delta \ln M D_{t-1} \\
&+\sum_{i=0}^{n 2} b_{i} \Delta G D P_{t-1} \\
&+\sum_{i=0}^{n 3} c_{i} \Delta I T R_{t-1}+\sum_{i=0}^{n 4} d \Delta E X R_{t-1}^{+} \\
&+g \ln E X R_{t-1}^{-} \\
&+\gamma_{0} \ln M D_{t-1}+\gamma_{1} \ln G D P_{t-1}+\gamma_{2} I T R_{t-1}+\gamma_{3} \ln E X R_{t-1}^{+}+ \\
& \gamma_{4} \ln E X R_{t-1}^{-}+\varphi_{t}
\end{aligned}
$$

All variables are as defined in Equation (1). Equation (5) can be used to test whether exchange rate variations has an asymmetric effects on the money demand for both short and long run. The F-test for joint significance is used to test for cointegration in the model with a null hypothesis of;

$\gamma_{0}=\gamma_{1}=\gamma_{2}=\gamma_{3}=\gamma_{4}=0$

The model in equation (5) is referred to as a Non-linear model (non-linerity comes from the construction of the two new variables of negative and positive signs). Shin et al. (2014) proposed that the ARDL method of cointegration by Pesaran et al. (2001) can be applied to the non-linear model in Equation (5), hence the usual F-test criteria can be applied also. From Equation (5), the short run effects are captured by the estimates of the coefficients of the first differenced variables. The coefficient estimate of $d$ measures the short run total impact of appreciation of the local currency on the movements in money supply, while $g$ measures a short run total impact of depreciation of the local currency on variations on money supply. If the estimated coefficient values of the positive and negative series have the same numerical value and the same sign(either both positive or negative) then it can be concluded that exchange rate changes have symmetric short run effects on money supply (Shin et al. 2014). The long run effects are interpreted from the estimates of the coefficients of the lagged level variables. The asymmetric or symmetric long run effects of changes in exchange rate on money supply are given by the sign and coefficients of the positive and negative. The Shin et al (2014) methodology made it possible to accommodate a nonlinear and asymmetric cointegration amongst the series under study. Moreso, it differentiate between short and long term influence of the regressors on the regressand variables. Added to that, the NLARDL does not require the integration order of the series to be identical as the case with other error correction models. Under this model, a combination of dissimilar orders of integration are allowed. Shin et al. (2014) also added that the model aid in solving the problem of multi colinearity through the choice of appropriate lag orders of the variables. 


\section{Results and Discussions}

Under this section, we carry out a preliminary descriptive analysis of the variables in the models. It enumerated on the descriptive statistics and correlation analysis. The section also discusses the unit root test results. It further discusses the results of the linear and nonlinear ARDL models under different sub-sections.

\subsection{Descriptive Statistics}

Table 1 depicts the descriptive statistics and pairwise correlation analysis of the variables. The variables are Money supply, GDP, exchange rate and interest rates for the period 1975 to 2016 annual data. From the table, it is noted that money supply is more volatile among all the variables having a standard deviation of 4.895 with an average of 4.241. Exchange rate has the lowest volatility suggesting a relative stability over the period. However, the data distribution show an asymmetric pattern in the distribution looking at the values of the skewness. The Jacque-Bera statistics show that the distribution is non normal thereby making it necessary to rely on asymmetric models as done in this study.

Table 1: Descriptive Statistics and Pair-wise correlations

\begin{tabular}{|c|c|c|c|c|}
\hline Variable & MD & EXR & GDP & ITR \\
\hline Mean & 4.24118 & 2.96674 & 3.32006 & 5.14684 \\
\hline Median & 1.94638 & 2.75006 & 1.72193 & 5.04167 \\
\hline Maximum & 1.605065 & 4.1483 & 1.23012 & 9.75001 \\
\hline Minimum & 4.8386 & 2.17688 & 1.1829 & 2.08166 \\
\hline Std Dev. & 4.895617 & 0.58734 & 3.59057 & 2.17061 \\
\hline Skewness & 1.15827 & 0.47572 & 1.12151 & 0.56337 \\
\hline Kurtosis & 3.0837 & 1.796 & 3.0099 & 2.21632 \\
\hline Jarque-Bera & 10.52286 & 4.60825 & 9.852899 & 3.68895 \\
\hline Probability & 0.005188 & 0.9984 & 0.007252 & 0.15811 \\
\hline MS & 1.0000 & & & \\
\hline \multirow[t]{2}{*}{ EXR } & 0.6648 & 1.0000 & & \\
\hline & $(0.0000)$ & - & & \\
\hline \multirow[t]{2}{*}{ GDP } & 0.9936 & 0.6929 & 1.0000 & \\
\hline & $(0.0000)$ & $(0.0000)$ & - & \\
\hline \multirow[t]{2}{*}{ ITR } & -0.5950 & -0.6751 & -0.6185 & 1.0000 \\
\hline & $(0.0000)$ & $(0.0000)$ & $(0.0000)$ & - \\
\hline
\end{tabular}

Looking at the correlation analysis, there exists a positive correlation between money supply and exchange rate. A positive correlation is also found between money supply and income (GDP), while a negative correlation between interest rate and money supply is established.

Following the descriptive analysis, and to unveil the unit root features of the variables, we conducted a unit root test on the variables; MD, EXR, INT and GDP at level and first difference on the basis of constant and a time trend specifications. Two different types of unit root tests were employed; Augmented Dickey-Fuller (ADF, 1979), and Phillips-Perron (PP, 1988) tests to ensure that the variables are either I(0) or I(1). Table (2) presents the results for ADF and PP. The Pesaran et al.(2001) and Shin et al.(2014) models does not accommodate an I(2) variable. From the results, none of the variables is stationary at $\mathrm{I}(2)$. Therefore we can go ahead with the linear and Non-linear ARDL estimations.

Table 2: Unit Root Tests

\begin{tabular}{|c|c|c|c|c|}
\hline \multicolumn{5}{|c|}{ A: Augmented Dickey Fuller } \\
\hline \multirow[t]{2}{*}{ Variable } & \multicolumn{2}{|c|}{ Level } & \multicolumn{2}{|c|}{ First Difference } \\
\hline & Intercept & With Trend & Intercept & With Trend \\
\hline LMD & $-2.6802 *$ & -2.2587 & $-5.0947 * * *$ & $-6.0072 * * *$ \\
\hline LEXR & -0.6097 & $-3.2567 *$ & $-4.9723 * * *$ & $-5.1229 * * *$ \\
\hline LGDP & -2.2973 & -2.0253 & $-6.1562 * * *$ & $-6.7516^{* * *}$ \\
\hline LITR & -1.7259 & $-3.4036^{*}$ & $-5.5958 * * *$ & $-5.5417 * * *$ \\
\hline \multicolumn{5}{|c|}{ B: Phillip-Peron } \\
\hline LMD & -3.3482 & -2.1551 & $-5.7623^{* * *}$ & $-6.3916^{* * *}$ \\
\hline LEXR & -0.6097 & -2.6208 & $-4.8797 * * *$ & $-5.0526 * * *$ \\
\hline LGDP & -2.2973 & -2.0253 & $-6.1597 * * *$ & $-6.7527 * * *$ \\
\hline LITR & -1.6684 & -2.5741 & $-6.2987 * * *$ & $-6.5715^{* * * *}$ \\
\hline \multicolumn{5}{|c|}{$\begin{array}{l}\text { Note:***, **,and } * \text { imply significance at } 1 \%, 5 \% \text { and } 10 \% \text { levels } \\
\text { respectively. The figures show the t-statistic value for testing the null } \\
\text { hypothesis that the variable possess a unit root. The Scwarz Information } \\
\text { Criterion (Schwert, 1987) is used in the lag length selection. The critical } \\
\text { values for constant without trend are }-3.479,-2.883 \text { and }-2.578 \text { while that of } \\
\text { constant with trend are }-4.028,-3.443 \text { and }-3.146 \text { for } 1 \%, 5 \% \text { and } 10 \% \\
\text { respectively. For PP the bandwidths are determined based on the Newey-West } \\
\text { using Bartlett Kernel.. The critical values for constant without trend are - } \\
3.479,-2.883 \text { and }-2.578 \text { while that of constant with trend are }-4.028,-3.443 \\
\text { and }-3.146 \text { for } 1 \%, 5 \% \text { and } 10 \% \text { respectively. The figures are based on } \\
\text { Mackinnon (1991). }\end{array}$} \\
\hline
\end{tabular}

\subsection{Estimations and Results}

After the preliminary descriptive and unit root analysis, two models of linear and nonlinear ARDL were estimated as specified in equations (2) and (5) respectively. A maximum of 2 lags was assigned (for annual data) on every first difference serie using the Akaike`s information criterion (AIC) to choose an optimum lag length. The estimated results for the ARDL model in equation (2) are reported in table (3). From the table, panel A carries the short run estimates, Panel B contains the long run estimates while panel $\mathrm{C}$ reported the joint significance F-Statistics test and diagnostic tests results. From panel A, a significant number of the coefficients are statistically significant. Although some of the coefficients shows an insignificant estimates in the shortrun, the good side of the results is that the error correction term is negative and highly significant with a very high speed of adjustment (84\%). This signifies that $84 \%$ of disequilibrium in the long run will be adjusted annually. 
Table 3: LINEAR ARDL Estimates

Panel A: Short-Run Coefficients

\begin{tabular}{|c|c|c|c|c|}
\hline Lag order & 0 & 1 & 2 & 3 \\
\hline$\Delta \mathrm{LMD}$ & - & $\begin{array}{c}0.095 \\
(0.461)\end{array}$ & $\begin{array}{c}0.206 \\
(0.121)\end{array}$ & - \\
\hline$\triangle \mathrm{LEXR}$ & $\begin{array}{c}-0.002 \\
(0.991)\end{array}$ & $\begin{array}{c}1.055 \\
(0.010)\end{array}$ & $\begin{array}{c}0.333 \\
(0.000)\end{array}$ & - \\
\hline$\triangle \mathrm{LGDP}$ & $\begin{array}{c}0.590 \\
(0.051)\end{array}$ & $\begin{array}{c}0.732 \\
(0.041)\end{array}$ & $\begin{array}{c}0.335 \\
(0.290)\end{array}$ & $\begin{array}{c}0.406 \\
(0.140)\end{array}$ \\
\hline$\triangle \mathrm{LITR}$ & $\begin{array}{l}-0.039 \\
(0.652)\end{array}$ & $\begin{array}{c}-0.294 \\
(0.000)\end{array}$ & $\begin{array}{l}-0.332 \\
(0.000)\end{array}$ & \\
\hline$E C T_{t-1}$ & - & $\begin{array}{c}-0.844 \\
(0.000) \\
\end{array}$ & - & - \\
\hline \multicolumn{5}{|c|}{ Panel B: Long-Run Coefficients } \\
\hline$L E X R$ & \multicolumn{4}{|c|}{$-1.642(0.031)$} \\
\hline LGDP & \multicolumn{4}{|c|}{$1.214(0.000)$} \\
\hline LITR & \multicolumn{4}{|c|}{$0.385(0.000)$} \\
\hline Constant & \multicolumn{4}{|c|}{$5.814(0.000)$} \\
\hline \multicolumn{5}{|c|}{ Panel C: Diagnostic Tests } \\
\hline $\mathrm{F}$ & \multicolumn{4}{|l|}{14.68} \\
\hline LM-Test & \multicolumn{4}{|c|}{$0.8705(0.6471)$} \\
\hline BGP Test & \multicolumn{4}{|c|}{$27.5288(0.1360)$} \\
\hline RESET & \multicolumn{4}{|c|}{$0.6277(0.4356)$} \\
\hline NORMAL & \multicolumn{4}{|c|}{$17.3695(0.0013)$} \\
\hline CUSSUMS & \multicolumn{2}{|l|}{ Stable } & & \\
\hline
\end{tabular}

a) Number in parenthesis are p-values

b) $\mathrm{F}=$ Bound test for cointegration. Upper bound critical values for F-Statistics at $5 \%$ level is 4.35 obtained from Pesaran et al (2001)

c) $\mathrm{LM}=$ Langrange Multiplier test for serial correlation

d) $\mathrm{BGP}=$ Breusch-Godfrey test for Heteroscedasticity

e) RESET= Ramsey`s Specification test

f) NORMAL $=$ Normality tests based on the test of skewness and kurtosis of residuals

The long run estimates in panel $\mathrm{B}$ indicates that all the variables in the model (exchange rate, income, interest rate) carries their a priori expected signs and are statistically significant. Nevertheless, this long run relationship could only be validated with the existence of a cointegration. The F-test joint significance estimates value of 14.68 in panel $\mathrm{C}$ show that it is above the upper bound critical value of 4.35 at the $5 \%$ significance level. This confirms the existence of a long run cointegration. However, Bahmani-Oskooee and Bahmani (2015) found that joint F-test of joint significance value to be less than the upper critical values. The diagnostic test results are reported in panel $\mathrm{C}$. to ensure a serial correlation free residuals, homescedastic, well specified and a normally distributed residuals, the respective estimates are reported. From the results, all the diagnostic tests are statistically insignificant with the exception of normality tests. Likewise a test for short and long run coefficients, following BahmaniOskooee and Bahmani (2015) for the CUSUM and CUSUMSQ tests were carried out. All coefficients are stable at 5\% significant levels for both CUSUM and CUSUMSQ.

Looking at the impact of the currency exchange rate on the money demand function, it is significant in both the short and long run period. However, basing the relationship on a linear manner might not actually expose the true effects of exchange rate on the money demand function since it has been acknowledged that exchange rate could have both positive and negative influence on money demand (Bahmani-Oskooee and Bahmani, 2015). With that, the nonlinear model in Equation (5) is estimated and the results presented in Table (4). From the short run results in panel $\mathrm{A}$, the variables representing
MYR depreciation $\triangle L E X R^{-}$bears a positive and significant coefficient while $\triangle L E X R^{+}$is insignificant suggesting the existence of an asymmetric effects of exchange rate movements on money demand over the short run period.

Table 4: Non-Linear ARDL Estimates

Panel A: Short-Run Coefficients

\begin{tabular}{|c|c|c|c|c|}
\hline $\begin{array}{l}\text { Lag } \\
\text { order }\end{array}$ & 0 & 1 & 2 & 3 \\
\hline$\triangle \mathrm{LMD}$ & - & $\begin{array}{c}0.375 \\
(0.003)\end{array}$ & $\begin{array}{c}0.599 \\
(0.000)\end{array}$ & - \\
\hline$\Delta L E X R^{+}$ & $\begin{array}{l}-0.047 \\
(0.668)\end{array}$ & $\begin{array}{c}1.164 \\
(0.000)\end{array}$ & - & - \\
\hline$\triangle L E X R^{-}$ & $\begin{array}{c}0.058 \\
(0.736)\end{array}$ & $\begin{array}{c}0.156 \\
(0.167)\end{array}$ & $\begin{array}{c}0.272 \\
(0.020)\end{array}$ & $\begin{array}{c}0.139 \\
(0.080)\end{array}$ \\
\hline$\triangle \mathrm{LGDP}$ & $\begin{array}{c}0.986 \\
(0.005)\end{array}$ & $\begin{array}{c}0.624 \\
(0.043)\end{array}$ & - & - \\
\hline$\Delta \mathrm{LITR}$ & $\begin{array}{c}-0.003 \\
(0.969)\end{array}$ & $\begin{array}{l}-0.070 \\
(0.505)\end{array}$ & $\begin{array}{c}-0.421 \\
(0.000)\end{array}$ & - \\
\hline$E C T_{t-1}$ & - & $\begin{array}{l}-0.228 \\
(0.000)\end{array}$ & - & \\
\hline \multicolumn{5}{|c|}{ Panel B: Long-Run Coefficients } \\
\hline$L E X R^{+}$ & \multicolumn{4}{|c|}{$-4.319(0.000)$} \\
\hline$L E X R^{-}$ & \multicolumn{4}{|c|}{$-6.246(0.000)$} \\
\hline LGDP & \multicolumn{4}{|c|}{$2.186(0.015)$} \\
\hline LITR & \multicolumn{4}{|c|}{$-3.012(0.000)$} \\
\hline Constant & \multicolumn{2}{|c|}{$18.132(0.000)$} & & \\
\hline \multicolumn{5}{|c|}{ Panel C: Diagnostic Tests } \\
\hline $\mathrm{F}$ & \multicolumn{4}{|c|}{15.402} \\
\hline LM-Test & \multicolumn{4}{|c|}{$1.802(0.4062)$} \\
\hline BGP Test & \multicolumn{4}{|c|}{$14.187(0.7168)$} \\
\hline RESET & \multicolumn{4}{|c|}{$2.020(0.1588)$} \\
\hline NORMAL & \multicolumn{4}{|c|}{$2.389(0.3028)$} \\
\hline CUSSUMS & \multicolumn{2}{|c|}{ Stable } & & \\
\hline
\end{tabular}

Wald (Joint significance) Wald (Short run) Wald (Long run)

$\begin{array}{lll}14.47(0.000) & \text { 8.692(0.003) } & 7.158(0.007)\end{array}$

Note: As Table 3

To confirm whether this extends to the long run period, we look at the long run coefficients estimates in panel B. From the results, it is clear that $\triangle L E X R^{-}$bears a highly significant estimate but the $\triangle L E X R^{+}$coefficient results does not conform to the results in the short run. Here both coefficients are statistically significant with an opposite sign suggesting the presence of an asymmetric effects. The negative coefficient of $\triangle L E X R^{+}$means that when the foreign currency say dollar appreciates, Malaysians keep less of their domestic currency. On the other hand, the negative sign of $\triangle L E X R^{-}$suggests that when a dollar depreciates against the Malaysian Ringgit, Malaysians will hold less of the domestic currency.

Overall, the results signifies that the impact of exchange rate on the money demand in Malaysia is through expectation changes rather than wealth effect channel. When the US dollar appreciates, people expects further appreciation, thereby keep more dollars and less Ringgits. When the dollar depreciates, since there are always expectations of dollar appreciations, people keep more dollars and less Ringgits instead. We then conclude that exchange rate changes have an asymmetric impact on Malaysian money demand function in the long run.

Taking a look at the other variables in the model, income elasticity bears the a priori positive sign and is highly significant. Interest rate possess its expected sign and is also significant. 
The joint significance F-statistic estimate of 14.40 is above the upper bound critical value of 4.01 at $5 \%$ level of significance. This imply that there exists a cointegration among the variables in the model. Panel $\mathrm{C}$ reported the diagnostic tests results which further confirm residuals free from serial correlation, homoscedastic, a well specified model, normally distributed errors and a stable CUSUM and CUSSUMSQ.

To further reinforce the existence of short and long run asymmetric impact of exchange rate on money demand, we follow Shin et al. (2014) recommendations to apply Wald test in testing for the equality of short and long run estimates of the coefficients. To test for long run asymmetry, we run a Wald test to confirm if $\rho_{3}=\rho_{4}$. The Wald test results are reported in panel $\mathrm{C}$ with a corresponding $\mathrm{p}$-values in parenthesis. The results supported the presence of an asymmetric effects of exchange rate on money demand in both short and long run period.

\section{Summary and Conclusion}

Literature on the determinants of money demand identified different macroeconomic variables to have influence money demand. Such variables among others include income and interest arte as scale and opportunity cost variables respectively. Mundell (1963) added exchange rate to the determinants of money demand. Several other studies have investigated the effects of exchange rate on money demand. A common feature of most of the studies on the relationship between exchange rate and money demand is that they have all assumed that the relationship is linear and that effects of exchange rate on money demand is symmetric. Nevertheless, of recent, studies such as Bahmani-Oskooee and Bahmani (2015) have shown that exchange rate have an asymmetric effect on money demand signifying a non-linear relationship.

In this study, we follow Bahmani-Oskooee and Bahmani (2015) and investigate whether exchange rate movements have symmetric or asymmetric impact on money demand in Malaysia. Estimating the Linear ARDL model of Pesaran et al.(2001), where all series are assumed to bear a symmetric impact on money demand, we established that the series have a short and long run effects. Exchange rate appears to have a significant long-run impact on money demand in Malaysia. Nonetheless, when we applied the NLARDL method of Shin et al.(2014) and distinguish between currency depreciation and appreciations, it has been established that the exchange rate movements hav an asymmetric effects on money demand at both short and long run period.

The policy implication for this findings is that policy makers that try to achieve their exchange rate objectives will be exposed to several other ways of intervention when they become aware that the effects of currency depreciation are distinct from those of appreciation.

\section{References}

Arango, S., \& Nadiri, M. I. (1981). Demand for money in open economies. Journal of Monetary Economics, 7(1), 69-83.

Arize, A. C., \& Nam, K. (2012). The demand for money in Asia: Some further evidence. International Journal of Economics and Finance, 4(8), 59-72.

Bae, Y., \& De Jong, R. M. (2007). Money demand function estimation by nonlinear cointegration. Journal of Applied Econometrics, 22(4), 767-793.

Bahmani-Oskooee, M., \& Bahmani, S. (2015). Nonlinear ARDL approach and the demand for money in Iran. Economics Bulletin, 35(1), 381-391.

Bahmani-Oskooee, M., \& Pourheydarian, M. (1990). Exchange rate sensitivity of demand for money and effectiveness of fiscal and monetary policies. Applied Economics, 22(7), 917- 925.

Bahmani-Oskooee, M., \& Rhee, H. J. (1994). Long-run elasticities of the demand for money in Korea: evidence from cointegration analysis. International Economic Journal, 8(2), 83- 93.

Bank Negara Malaysia (2015). www.bnm.gov.my

Dickey, D. A., \& Fuller, W. A. (1979). Distribution of the estimators for autoregressive time series with a unit root. Journal of the American statistical association, 74(366a), 427- 431.

Hossain, A. A., \& Arwatchanakarn, P. (2017). Does money have a role in monetary policy for price stability under inflation targeting in Thailand? Journal of Asian Economics, 53, 37-55.

Ibrhim, M. H. (2001). Financial factors and the empirical behavior of money demand: A case study of Malaysia. International Economic Journal, 15(3), 55-72.

Mcgibany, J. M., \& Nourzad, F. (1995). Exchange rate volatility and the demand for money in the US. International Review of Economics \& Finance, $4(4), 411-425$.

McNown, R., \& Wallace, M. S. (1992). Cointegration tests of a long-run relation between money demand and the effective exchange rate Journal of International money and Finance, 11(1), 107-114.

Mundell, R. A. (1963). Capital mobility and stabilization policy under fixed and flexible exchange rates. Canadian Journal of Economics and Political Science/Revue canadienne de economiques et science politique, 29(4), 475-485.

Pesaran, M. H., Shin, Y., \& Smith, R. J. (2001). Bounds testing approaches to the analysis of level relationships. Journal of applied econometrics, 16(3), 289-326.

Phillips, P. C., \& Perron, P. (1988). Testing for a unit root in time series regression. Biometrika, 75(2), 335-346.

Quadry, M. O., Mohamad, A., \& Yusof, Y. (2017). On the Malaysian Ringgit exchange rate determination and recent depreciation. International Journal of Economics, Management and Accounting, 25(1), 1.

Shahbaz, M., Mallick, H., Mahalik, M. K., \& Sadorsky, P. (2016). The role of globalization on the recent evolution of energy demand in India: Implications for sustainable development. Energy Economics, 55, 52-68.

Shin, Y., Yu, B., \& Greenwood-Nimmo, M. (2014). Modelling asymmetric cointegration and dynamic multipliers in a nonlinear ARDL framework. In Festschrift in Honor of Peter Schmidt (pp. 281-314). Springer New York.

Tan, E. C. (1997). Money demand amid financial sector developments in Malaysia. Applied Economics, 29(9), 1201-1215.

About Author (s):

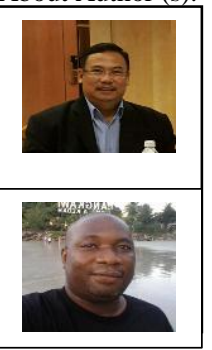

Hussin Abdullah is lecturer of Monetary Economics at the School of Economics, Finance and Banking, UUM. His research interests include the area of applied macroeconomics, financial and monetary economics and economic growth.

Shehu El-Rasheed is a PhD candidate and now waiting for his viva. 